\title{
Una mediación ética, psicológica y ecologizante
}

\section{Ethical, Psychological and Ecologicalizing Mediation}

\author{
José Alberto Rubí Barquero \\ Escuela de Filosofía \\ Universidad Nacional de Costa Rica \\ Heredia, Costa Rica \\ joserubi54@yahoo.com
}

Recibido 10 de noviembre de 2010 • Aceptado 09 de marzo de 2011

\begin{abstract}
Resumen. En este artículo hago hincapié en la importancia de la mediación pedagógica en el proceso educativo y paso a señalar cómo la mediación se enriquece si se toman en cuenta consideraciones de tipo ético como la legitimidad del otro; de tipo psicológico, rescatando del valor de la empatía, y de tipo ecologizante, resaltando la importancia de la contextualización como medio pedagógico.
\end{abstract}

Palabras claves. Educación, mediación pedagógica, ética, empatía, contexto.

Abstract. This paper highlights the importance of pedagogical mediation in the educational process and how mediation can be improved through certain considerations: ethical (legitimacy of others), psychological (the value of empathy) and ecologicalizing (the importance of contextualization as a pedagogical means).

Keywords. Education, pedagogical mediation, ethics, empathy, context.

"Un día Chuang -tzú y un amigo estaban caminando por la orilla de un río.

"¿Qué deliciosamente gozan los peces en el agua!", exclamó Chuang-tzú.

"Tú no eres pez", dijo su amigo. "¿Cómo sabes si los peces están gozando o no?"

"Tú no eres yo", respondió Chiang-tzú, "¿Cómo sabes que no sé que los peces están gozando?"

Historia taoísta

\section{Introducción}

Conforme leía el libro Mediación pedagógica, de Gutiérrez y Prieto (2004) y me percataba de la importancia del tema ahí tratado, me surgió la pregunta de cómo abordarlo desde el tema de la ética arraigada en el nuevo saber ecológico. Con esta pregunta en mente continué mis lecturas hasta toparme, en el libro Ecopedagogía y ciudadanía planetaria, de Gutiérrez (1997) con una cita de

Doctor en Educación y Licenciado en Filosofía. Es profesor en la Escuela de Filosofía de la Universidad Nacional de Costa Rica. 
Maturana -en la página 80- que me pareció reveladora y que concibe la preocupación ética como la capacidad de ver al otro como legítimo otro.

Sabiendo, en ese momento, que la mediación pedagógica privilegia al aprendiente antes que los contenidos, dicha visión de la ética me pareció perfecta para formar parte de la mediación. Además, la encontré muy a tono con lo significado por la palabra "empatía", una palabra que tiene mucho que ver con mi vida, tanto personal como profesional, y que yo siento que en el tema de la mediación pedagógica merece un lugar central.

Ya tenía claro, entonces, el papel de lo ético en la mediación; sin un reconocimiento pleno del otro, me dije, ninguna mediación va a estar completa. Y como, por añadidura, dada esa concepción de lo ético que lo acerca tanto al tema de la empatía, surgió lo psicológico como otro componente de la mediación que deseo destacar en este trabajo. Si el aprendiente es un ser humano y, por lo mismo, un ser rico y complejo, cómo llegarle adecuadamente, me pregunté, sin tomar en cuenta lo mejor del saber psicológico. No se puede, fue la respuesta.

Me faltaba, para mis propósitos en este texto acerca de mediación desde la nueva ética, asignarle un papel a lo ecológico. Un papel, quería yo, donde lo ecológico aportara, no tanto desde sus contenidos, sino desde su forma. Y creo haber encontrado la clave en un párrafo del libro La cabeza bien puesta, de Morin (1999) -lo cito completo más adelante- donde él reconoce la existencia de un estilo de pensamiento al que califica como "ecologizante". Este feliz hallazgo de Morin me da pie para hablar de lo ecológico en la mediación o, igualmente, de una mediación ecologizante.

\section{Un acercamiento personal}

En marzo del 61 entré a primer grado de la escuela. Hoy, 45 años después, reconozco que se trataba de una escuela peculiar para esa época. Con peculiar no quiero decir alternativa sino que, aun tratándose de una época claramente androcéntrica, esta escuela exageraba la nota. Entre otras cosas, porque hasta donde yo recuerdo, todo el personal, tanto el administrativo como el docente, estaba conformado por hombres. Y como los estudiantes también éramos solo hombres, había razón de que se la mencionara como "una escuela de hombres".

Esta escuela estaba en San José y aunque se pagaba poco, había que pagar. Si no fuera porque hay cosas que lo hacen recordar a uno, yo de mi gusto posiblemente no me acordaría del año que pasé en esa institución. Así que el día que vi la película "Los chicos del coro" (Perrin, Cohn y Mauvernay, 2004), no pude evitar los recuerdos, las comparaciones y el asombro por las semejanzas. Con decirles que hasta físicamente mi maestro de primer grado era muy parecido a Rachin, el personaje que en este filme es el director del Centro Educativo de Protección de Menores, lugar conocido como "Fondo del estanque".

Mi maestro, pese a que no se ufanaba de tener un credo pedagógico inspirado en la tercera ley de Newton, la que dice que a cada acción siempre se opone una reacción igual, como si lo hace en la película el director Rachin, en su práctica pedagogica era igualmente newtoniano, pura física clásica: para eso tenía a su disposición la cabeza del estudiante y la pared del aula, para que, golpeando una contra la otra, ocurriera el milagro de la acción correctiva.

Con películas como esta, que la he vuelto a ver un par de veces más con mis estudiantes del curso Arte en el cine, y con las lecturas relacionadas con la mediación pedagógica, es imposible no traer a colación todo cuanto han hecho con uno en el paso por las aulas, con el propósito de educarlo y lo que uno ha venido haciendo hasta el día de hoy con los aprendientes, cuando se es profesor, como en mi caso. En esos momentos, viéndome en esos espejos que me devuelven mi 
imagen pero cuestionada, asisto a un hecho extraordinario: al despertar de la conciencia pedagógica, al descubrimiento de que tan importante es saber lo que se está enseñando, manejar con propiedad los contenidos, como saber a qué recursos echar mano para que el aprendiente realmente aprenda.

Estos recursos que tienen que ver con el cómo se enseña, son de la más diversa índole. Desde el tema original de la nueva ética voy a resaltar tres que me parecen fundamentales para una buena mediación pedagógica.

\section{Lo ético en la mediación}

Una mediación carente de preocupación ética corre el riesgo de quedarse en los contenidos, como si estos fueran los fines supremos del proceso educativo, y de olvidarse de los aprendientes. Pero si, además, lo ético se sustituye por lo moral, como suele suceder, entonces el "educador" siente que cumplió con su deber cuando abarcó todos los contenidos, cuando le alcanzó el tiempo para ver "toda la materia", gracias a que logró mantener a los estudiantes bajo control. Si los estudiantes aprendieron o no, es algo que se verá con el examen y no durante el proceso en el aula. Se cumple aquí, entonces, lo que señala Allan Watts, citado por Gutiérrez (1997, p. 80).

(...) cuando un hombre da pan a otro para ser caritativo, vive con una mujer para ser fiel, come con un negro para no tener prejuicios y se niega a matar para ser pacífico, es frío como una almeja. No ve realmente a la otra persona. Nada es realmente más inhumano que las relacionas humanas basadas en la moral.

Cuando lo ético inspira la mediación, esta se centra en el aprendiente. Una clave para constatar la efectiva presencia de lo ético en la mediación la encuentro en estas palabras de Maturana, citado por Gutiérrez (1997, p. 81)

Si yo no soy capaz de ver al otro como legítimo otro, no tengo preocupación ética. La preocupación ética nunca va más allá de los dominios sociales en que surge. Se funda en la emoción, en el amor, en la visión del otro. Si uno no ve al otro no le importa lo que al otro le pase. Cuando uno ve al otro, cuando se fija en lo que le pasa al otro, empieza a importarle, antes no. La preocupación ética es la preocupación por lo que le pasa al otro y por el efecto de las acciones de uno. Si a mí me preocupa las consecuencias de mis acciones sobre el otro, quiere decir que tengo una preocupación ética.

En la película "Los chicos del coro", el director Rachin encarna una versión de lo moral, trabaja con la idea de que el que la hace la paga y está siempre dispuesto a cumplir con el deber de castigar al infractor. Su mecánica forma de "mediar" no logra redimir a nadie, solo se percata de lo que hacen los chicos y no de por qué lo hacen. De aquí que su principio de acción y reacción se le vuelva en su contra, cuando uno de ellos, el más endurecido por tanto golpe recibido, le prende fuego al Centro.

Opuesto a este accionar mecanicista, está el accionar del profesor de música (Clement Mathieu), a él le inspira la preocupación ética, que es la "preocupación por lo que le pasa al otro y por el efecto de las acciones de uno". Desde este influjo y con recursos mediadores como su comprensión del otro (no castiga sino que pone al infractor a ver las consecuencias de sus actos), sentido del humor y su fe en el poder de la música como medio para "cambiar a las personas y transformar el mundo", el profesor Mathieu hace nacer la esperanza en "el fondo del estanque". 


\section{Lo psicológico en la mediación}

Escribo este subtítulo y una lectura de esas de impacto que hice años atrás, el libro Summerhill (1994), se apodera de mis pensamientos. Porque recuerdo que ahí aprendí que cuando estamos metidos en el asunto de educar, el manejo que se haga del factor psicológico es decisivo. Hago una pausa y leo el título de un artículo que recién me enviaron por el correo electrónico "Los chicos del coro: Música y afecto en las relaciones educativas", dejo de lado, imperdonablemente, la alusión directa a la música, que invita a desarrollar el papel de lo artístico en la mediación, y me detengo en la palabra "afecto" que me confirma la importancia mencionada de lo psicológico.

Claro, porque cuando de relaciones entre personas se trata, todos nuestros actos cuentan y hasta el más pequeño, una fugaz mirada de reprobación, por ejemplo, puede marcar la diferencia.

Como el tema psicológico es tan rico y tan complejo, esta vez voy a quedarme con uno de sus componentes, la empatía. Esta palabra y su significado tienen mucho que ver con mi gilánica vida y no me sorprende que para muchos, como nos lo hace ver Eisler (1990), sea un asunto de mujeres y de hombres afeminados. Ni me sorprende ni me molesta; al contrario, creo que contar con una buena dotación de empatía es toda una ventaja, que "invertir" en su enriquecimiento es una excelente "inversión”. Creo, también, que si mediar pedagógicamente es ponerse en el lugar del aprendiente, del interlocutor cuando se intenta desde un texto de Gutiérrez y Prieto (2004), sin empatía no se podría hacer. Un educador sin empatía es un cuadrado redondo, es decir, una contradicción.

Ejercicios de empatía. Para avanzar en esto que Morin llama "la comprensión de lo humano", un buen ejercicio lo constituye la literatura: leer novelas, cuentos, poesía, es una forma de cultivar nuestro sentido empático. El teatro, la actuación, también; ese personaje que me asignan es otro, no soy yo, pero debo asumirlo, darle vida desde mi vida, ponerme en su lugar. Igual pasa con el cine, ver películas es como ir integrando otras vidas a la vida de uno.

Con la empatía tenemos la experiencia de lo holístico, por la empatía siento que soy vida, vida que vive en la vida, que nada me separa del árbol que es vida, del río que es vida, del pájaro que es vida, que soy uno con el pájaro, con el río, con el árbol y que cuando digo yo es lo mismo que si dijese nosotros. Es cuestión de abrirnos. Abrirnos para ver, para escuchar, para tocar, para sentir. Si nos abrimos, la empatía, que es medio y fin a la vez, se nutre con cada suceso de la vida.

En Suecia [-nos cuenta Eisler (1990)-] ya se han promulgado leyes para prohibir la venta de juguetes bélicos, los que han servido tradicionalmente para enseñar a los niños una falta de empatía con aquellos a quienes hieren, así como todas las otras actitudes y conductas que los hombres requieren para matar a otros de su misma especie. Y las concentraciones a favor de la paz de millones de personas en todo el planeta, son una evidencia impresionante de una renovada conciencia, de nuestra vinculación con la totalidad de la humanidad. (p. 114)

No solo se media desde la empatía, se media para la empatía. En la película "Los chicos del coro", uno de mis puntos de referencia en este trabajo, el sentido empático, proveniente de un saber psicológico humanístico, junto con otros medios como el sentido del humor y el poder de la música, no se quedan en ser solamente medios, están al servicio de un fin igualmente empático, la solidaridad. De aquí que una estrofa de la canción central de la película dice así:

"Mira en el camino a los niños olvidados,

perdidos, dadles la mano para llevarlos a otro mañana" 


\section{Lo ecológico en la mediación}

La idea de que el saber ecológico debe permear a la mediación pedagógica, es decir, a la forma que adoptamos para que el aprendiente experimente gozo en el acto de aprender, me la sugirió el siguiente pasaje del libro de Edgar Morin (1999) La cabeza bien puesta:

A partir de ahora, la educación debe incluir

inaplazablemente las cuatro

grandes tendencias de la ecología:

la ambiental, la social, la mental y la

integral o profunda (...). (Boff, 2008, parr. 3)

El desarrollo de "la aptitud de contextualizar tiende a producir el surgimiento de un pensamiento 'ecologizante' en el sentido de que sitúa todo acontecimiento, información o conocimiento en una relación inseparable con el medio -cultural, social, económico, político y, por supuesto, natural-. No hace más que situar un acontecimiento en su contexto, incita a ver cómo este modifica al contexto o cómo le da luz diferente" (Morin, 1999, p. 27). Un pensamiento de este tipo se vuelve inseparable del pensamiento de lo complejo, pues no basta con inscribir todas las cosas y hechos en un "marco" u "horizonte". Se trata de buscar siempre las relaciones e inter-retro-acciones entre todo fenómeno y su contexto, las relaciones recíprocas entre el todo y las partes: cómo una modificación local repercute sobre el todo y cómo una modificación del todo repercute sobre las partes.

Al mismo tiempo, se trata de reconocer la unidad dentro de lo diverso, lo diverso dentro de la unidad; reconocer, por ejemplo, la unidad humana a través de las diversidades individuales y culturales; las diversidades individuales y culturales a través de la unidad humana. Finalmente, un pensamiento que vincule se abre hacia el contexto de los Contextos, el contexto planetario" (Morin, 1999).

El saber ecológico, ciertamente, es un saber ejercitado para ver a los seres vivos en su contexto, formando una unidad inseparable. Ya en el aula, este pensamiento "ecologizante" debe inspirar un principio pedagógico según el cual explicar es contextualizar, mostrar o sugerir las relaciones que guardan las distintas cosas entre sí. Mi experiencia como aprendiente me confirma lo interesante que resulta poder ver las cosas -un hecho histórico, una obra de arte, una creencia religiosa, etc.- en relación con su contexto, dado que el contexto ayuda a entender, y entender produce gozo.

A los mismos que les conviene frenar el despliegue de la empatía, ocultando, por ejemplo, las imágenes que muestran las consecuencias de un bombardeo, imágenes que moverían a la compasión y al cuestionamiento, a esos mismos les conviene presentar los hechos fuera de contexto, desconectados de su génesis histórica. Estos han comprendido el potencial del pensamiento ecologizante y nos invaden cotidianamente, desde sus poderosas cadenas televisivas, con una versión invertida del mismo.

Como educador, me resisto a ser un medio informativo, la información por sí misma está lejos de ser conocimiento, y el conocimiento no debe confundirse con la sabiduría.

\section{Conclusión}

He destacado tres aspectos -ético, psicológico y ecológico- que a mi juicio deben tomarse muy en cuenta a la hora de mediar. Sé que la mediación, por ser un tema rico y complejo, involucra 
muchos más aspectos; pero me he fijado con especial interés en esos tres. También sé que a la hora de mediar, los diferentes aspectos deben presentarse entrelazados unos con otros, formando una unidad y que solo para los efectos de este trabajo, convenía presentarlos por separado.

Realizando las lecturas de este tema, no pude evitar cotejar lo que ahí se apuntaba con mi forma de hacer las cosas en el aula. Este cotejo se tradujo en un refrescante despertar de mi conciencia pedagógica, un despertar que por mi particular historia personal, gilánica, como la llamé en otro momento, me llevó al tema de la empatía y a destacar su papel en la mediación. A lo mejor, me dije, la identificación de la mujer con las tareas educativas vaya más allá de un asunto de división social del trabajo y tenga que ver con motivos más profundos, como podría serlo un posible origen, en lo femenino que todos llevamos dentro, del sentido empático. De ser así, me pareció explicable que, a pesar de mi ignorancia y hasta de mis prejuicios en relación con la pedagogía, a la que ni siquiera distinguía de la didáctica, mucho de lo que he venido haciendo como profesor, visto desde mi nueva conciencia, no me parezca tan salido de tono.

\section{Referencias bibliográficas}

Boff, L. (2008). Educación ecocentrada. piensaChile..com Recuperado de http://www.piensachile. com/content/view/3998/2/

Eisler, R. (1990). El cáliz y la espada. Santiago, Chile: Editorial Cuatro Vientos.

Gutiérrez, F. (1997). Ecopedagogía y ciudadanía planetaria. San José, Costa Rica: ILPECEditorial.

Gutiérrez, F. y Prieto, D. (2004). Medicación pedagógica. Santiago, Chile: Prodessa, Ediciones la copia fiel.

Morin, E. (1999). La cabeza bien puesta. Buenos Aires: Ediciones Nueva Visión.

Neill, A. S. (1994). Summerhill. Un punto de vista radical sobre la educación de los niños. Madrid: Fondo de Cultura Económica.

Perrin, J., Cohn, A. y Mauvernay, N. (Productores) y Barratier, C (Director). (2004). Los chicos del coro [Película]. Francia: Centre National de la Cinématographie (CNC), Canal+, Vega Film, France 2 Cinéma, CP Medien AG, Procirep, Banque Populaire Images 4, Dan Valley Film AG, Galatée Films, Novo Arturo Films, Pathé Renn Productions. 